\title{
Peroxidizing Phytotoxic Activity of Pyrazoles
}

\author{
Hitoshi Kohno, Chifuyu Ogino, Tetsuji Irda, Seiji Takasuka, \\ Yukiharu Sato, Beate Nicolaus, * Peter BöGeR* \\ and Ko WAKABAYASHI \\ Graduate School of Agricultural Science, Tamagawa University, \\ Tamagawa-gakuen, Machida 194, Japan \\ *Lehrstuhl für Physiologie und Biochemie der Pflanzen, Universität Konstanz, \\ D-78434 Konstanz, Germany
}

(Received August 17, 1994; Accepted February 15, 1995)

\begin{abstract}
Using autotrophic Scenedesmus cells and maize protoporphyrinogen-IX oxidase, twelve pyrazole compounds recently synthesized were assayed with respect to peroxidizing phytotoxic activity. Three pyrazoles, namely 1-(4-chloro-2-fluoro-5-propargyloxyphenyl)-3,5-dimethyl4-nitropyrazole, 5-amino-4-cyano-1-(2,6-dichloro-4-trifluoromethylphenyl)pyrazole and 5chloro-1-(4-chloro-5-difluoromethoxy-2-fluorophenyl)-3,4-tetramethylenepyrazole, strongly inhibited growth of the Scenedesmus cells and caused severe chlorophyll deficiency (bleaching activity) at a $10^{-6} \mathrm{M}$ concentration. The three pyrazoles mentioned were selected for a further quantitative study to determine whether the chlorophyll decrease observed was due to inhibition of pigment biosynthesis or to peroxidative destruction of existing chlorophyll. The pyrazoles inhibited protoporphyrinogen-IX oxidase, caused not only accumulation of protoporphyrin-IX but also light-induced ethane formation. Thus, the three pyrazoles (1, 11 and 12) were identified as peroxidizing herbicides. A 1-(4-chloro-2-fluoro-5-substituted)phenyl moiety at the pyrazole ring appears to be essential for producing active peroxidizing compounds.
\end{abstract}

\section{INTRODUCTION}

Many possible candidates for bleaching herbicides have been synthesized in the last ten years, ${ }^{1)}$ but their peroxidizing activity has not yet convincingly been determined. Chlorophyll decrease, protoporphyrin-IX (Proto-IX) accumulation and light-induced ethane formation in Scenedesmus cultures treated with wellknown peroxidizing compounds, such as oxyfluorfen or chlorophthalim, have been determined as parameters for peroxidizing activity and applied for the peroxidation assay of new compounds. ${ }^{2-5}$ Recently, the protoporphyrinogen-IX oxidase (Protox) inhibition by these compounds has been included for the peroxidation assay. ${ }^{6}$ ) In this paper, the peroxidizing activity of new candidates for bleaching pyrazole compounds was investigated using Scenedesmus acutus cells and maize Protox.

\section{MATERIALS AND METHODS}

\section{Chemicals}

1-Aryl-3, 5-dialkyl-4-(un)substituted pyrazoles (1-10) were prepared by the condensation reaction of corresponding hydrazines with 3(un)substituted 2,4-pentanediones or their homologues. ${ }^{7)}$ 5-Amino-4-cyano-1-(2, 6-dichloro-4-trifluoromethylphenyl)pyrazole $\quad(\mathbf{1 1}$; M \& B 39279) was synthesized from ethoxymethylenemalononitrile and 2,6-dichloro-4-(trifluoromethyl)phenylhydrazine in refluxing acetic acid, according to Hatton et al..$^{8)}$ 5Chloro-1-(4-chloro-5-difluoromethoxy-2-fluorophenyl)-3,4-tetramethylenepyrazole (12) was synthesized by the reaction of 2-(4-chloro-5difluoromethoxy-2-fluorophenyl)-1, 2, 4, 5, 6, 7hexahydro- $3 H$-indazol-3-one, prepared from 2ethoxycarbonylcyclohexanone and the corresponding hydrazine, with phosphorus oxychloride. ${ }^{\text {) }}$ Oxyfluorfen (13), 2-chloro-4-tri- 
fluoromethylphenyl 3 - ethoxy - 4 - nitrophenyl ether, was prepared by treating 1,3-bis(2chloro - 4 - trifluoromethylphenoxy) - 4 - nitrobenzene with ethanolic $\mathrm{KOH} .{ }^{10)}$ Two cyclic imides, S-23142 (14; $N$-(4-chloro-2-fluoro-5propargyloxyphenyl) - 3, 4, 5, 6 - tetrahydrophthalimide) and chlorophthalim (15; N-(4chlorophenyl)-3, 4, 5, 6-tetrahydrophthalimide), were prepared by the condensation reaction of 3,4,5,6-tetrahydrophthalic anhydride and the appropriate anilines, according to our method given elsewhere. ${ }^{3)} \quad$ All reaction products were purified by recrystallization and/or column chromatography, and their structures were confirmed by IR-, NMR-spectroscopy and elementary analysis for $\mathrm{C}, \mathrm{H}$ and $\mathrm{N}$ (also halogen for some compounds).

Analytical-grade chemicals for algae cultivation were purchased from Merck AG, Darmstadt, and other fine chemicals, including authentic Proto-IX and buffers, were from Sigma, München, Germany.

\section{Phytotoxic Assays of Compounds \\ 2.1 Algae cultivation}

The green microalgae, $S$. acutus, was grown autotrophically in a sterile liquid culture by gassing air enriched with $4 \%(\mathrm{v} / \mathrm{v})$ of $\mathrm{CO}_{2}$ according to Nicolaus et al. ${ }^{11}$ The algae were grown for $24 \mathrm{hr}$; the cultivation started with a cell density of $1 \mu \mathrm{l}$ packed cell volume $(\mathrm{pcv}) / \mathrm{ml}$ suspension.

\subsection{Determination of phytotoxic activities using S. acutus}

Each test compound dissolved in methanol was applied at the required concentration to a 24-hr old algae cell suspension (with a density of $2 \mu \mathrm{l} \mathrm{pcv} / \mathrm{ml}$ of cell suspension). The final methanol concentration did not exceed $0.1 \%$. Experiments were performed in gas tight 9-ml vials. Two milliliters of algae suspension containing $5 \mathrm{~mm}$ of $\mathrm{NaHCO}_{3}$ was shaken in a Warburg apparatus for $16 \mathrm{hr}$ at $22^{\circ} \mathrm{C}$ in the light $(17,000$ lux $)$. After incubation, cell growth, chlorophyll content and ethane formation were determined. Cell growth was expressed as $\mathrm{pcv} / \mathrm{ml}$ of the algae culture volume. Total chlorophyll content was determined spectroscopically in methanolic extracts. Ethane was determined by gas chromatography.
The $\mathrm{pI}_{50}$ values of growth and chlorophyll decrease, the negative logarithms of the molar $I_{50}$, were used to quantify the influence of the compound on growth and chlorophyll content. The $\mathrm{pI}_{50}$ (Ethane) was estimated from $\mathrm{I}_{50}$ (Ethane), the molar concentration which gives half of the hypothetical maximum of lightinduced ethane formation by autotrophic Scenedesmus. ${ }^{2)}$

Proto-IX accumulation in the presence of compounds $\left(10^{-6} \mathrm{M}\right)$ was determined after a 1-hr incubation according to Watanabe et al. ${ }^{4)}$ Proto-IX in the extract was measured by highpressure liquid chromatography (HPLC). The value was expressed as nmol Proto-IX per milliliter of packed cell volume.

\subsection{Determination of protoporphyrinogen-IX oxidase (Protox) inhibition, $p I_{50}$ (Protox)}

Determination of the Protox inhibition was carried out according to the method of Nicolaus et al. ${ }^{12)}$ see details in that reference. Maize seeds (Zea mays cv. Anjou) were germinated for 6 days in the dark at $30^{\circ} \mathrm{C}$. The seedlings were harvested after exposure for 2-4 hr to the light. After homogenizing maize seedlings, purified plastids were prepared by differential centrifugation steps for determination of Protox activity. After adding the compounds to the assay mixture containing the plastids, inhibition of Protox activity was expressed by the amount of Proto-IX formed, which was measured by a Hitachi F 2000 fluorescence photometer.

The $\mathrm{pI}_{50}$ (Protox) was obtained by plots of the reciprocal initial enzyme activity vs. the substrate concentration.

\section{RESULTS AND DISCUSSION}

\section{Bleaching Activity of 1-Arylpyrazoles}

The bleaching herbicidal activity of 1-arylpyrazoles has recently been documented. ${ }^{7-9)}$ The method of measuring chlorophyll decrease in the presence of compounds during a shortterm incubation of unicellular green microalgae, S. acutus, provides a convenient and useful index of bleaching activity. ${ }^{2,8,6,11)}$ The bleaching phytotoxic activity of $p$-nitrodiphenyl ethers, ${ }^{5)}$ cyclic imides, ${ }^{3,12)}$ 1,2,4-triazolidines, ${ }^{2,3,12)}$ 1,3,4-thiadiazolidines ${ }^{2,6)}$ and oxazolidines $^{13}$ ) has already been determined using this assay system in our laboratory. 
The term "bleaching" generally refers to a decrease in the amount of photosynthetic pigments, e.g. chlorophylls or carotenoids, after a certain growth period of Scenedesmus in the presence of a compound as compared with the untreated control. ${ }^{14)}$ This pigment deficiency can be caused either by inhibition of biosynthesis of the pigments or by the peroxidative destruction of already-formed pigments. An effect of compounds on the biosynthesis of chlorophyll or carotenoids is quantitatively determined using heterotrophic Scenedesmus cells cultures in the dark, ${ }^{3,14}$ because the peroxidative destruction of pigments occurs only in autotrophic cells cultured in the light. The twelve pyrazole compounds (1-12 of Table 1) in this study did not affect the carotenoid content at the $10^{-6} \mathrm{M}$ concentration applied when the cells were cultured heterotrophically in the dark for $48 \mathrm{hr}$ (data not shown). Subsequently the influence of the twelve pyrazoles on growth and chlorophyll content of autotrophic Scenedesmus cells were investigated again using a $10^{-6} \mathrm{M}$ concentration of compounds during a 16-hr incubation period. The results are shown in Table 1.

Bleaching activity indicated by the chlorophyll decrease in autotrophic Scenedesmus cells in the light was rather different among the pyrazole compounds assayed. Compounds $\mathbf{1}$, $\mathbf{1 1}$ and $\mathbf{1 2}$ inhibited growth of the Scenedesmus cells and exhibited a chlorophyll decrease of more than $45 \%$ at the $10^{-6} \mathrm{M}$ concentration, while the reference bleachers, oxyfluorfen (13), S-23142 (14) and chlorophthalim (15), showed a chlorophyll decrease of 92,74 and $72 \%$, respectively. Other pyrazole compounds assayed (2-10) were found to be less active bleachers. The bleaching activity of the pyrazole with an alkylene moiety (e.g., 5-chloro-1-(4chloro-5-difluoromethoxy-2 -fluorophenyl) -3, 4tetramethylenepyrazole (12)) was higher than those of other non-bicyclic pyrazoles (1-10), except for 5-amino-4-cyano-1-(2,6-dichloro-4trifluoromethylphenyl)pyrazole (11). This finding resembles the structure-activity relationship of bleaching cyclic imide herbicides. ${ }^{15)}$ A suitable lipophilicity due to the alkylene group may play an important role also in the activity of the pyrazole compounds, producing the strong chlorophyll decrease in the cells. Also in the series of non-bicyclic pyrazole compound assayed, the 1-(4-chloro-2-fluoro-5-propargyloxy-(or isopropoxy-)phenyl) group is an essential moiety of the cyclic imide bleachers to bring about extremely high bleaching activity. ${ }^{15)}$ Generally the bleaching activity of non-bicyclic pyrazoles (1-10) was rather weak, compared with those of cyclic imide bleachers with the same aryl moiety (cf. chlorophyll inhibition of compounds $\mathbf{1}$ and $\mathbf{1 4}$ in Table 1). The three pyrazoles $(\mathbf{1}, \mathbf{1 1}$ and 12), exhibiting strong bleaching activity in the autotrophic Scenedesmus cells, were selected for a further quantitative study to elucidate which mechanism of chlorophyll deficiency prevails in Scenedesmus.

\section{Peroxidizing Activity of Selected 1-Aryl- pyrazoles}

The first plant response against the so-called peroxidizing herbicides, e.g. p-nitrodiphenyl ethers, cyclic imides, or triazolidines is inhibition of chlorophyll biosynthesis in chloroplasts. This inhibition is always accompanied with an abnormal accumulation of tetrapyrrole. ProtoIX, the main tetrapyrrole intermediate accumulated, is instrumental as a photosensitizer in the light and induces radical formation with subsequent destruction of thylakoid membranes, producing short-chain hydrocarbons (mostly, ethane in autotrophic Scenedesmus cells because their membrane lipids contain $\alpha$-linolenate). The Protox inhibition by peroxidizing herbicides correlates quite well not only with the peroxidative ethane formation, but also with the decrease of chlorophylls and carotenoids. ${ }^{1)}$ Five phytotoxic parameters, growth inhibition ( $\mathrm{pI}_{50}$ (Growth)), decrease of chlorophyll content $\left(\mathrm{pI}_{50}\right.$ (Chlorophyll)), ethane formation ( $\mathrm{pI}_{50}$ (Ethane)), protox inhibition ( $\mathrm{pI}_{50}$ (Protox)) and Proto-IX accumulation (Proto-IX), have been used to assay peroxidizing activity of compounds. Protox inhibition is measured with the enzyme from etioplasts, ${ }^{12,16)}$ the other four phytotoxic parameters are readily obtained using autotrophic Scenedesmus cells. ${ }^{12)}$ Phytotoxic activities determined for the three selected bleaching pyrazoles $(\mathbf{1}, \mathbf{1 1}$ and $\mathbf{1 2})$ are shown in Table 2, indicating $\mathrm{pI}_{50}$ values for growth inhibition, chlorophyll decrease, ethane forma- 
Table 1 Influence of pyrazole derivatives $(1.0 \mu \mathrm{M})$ on growth and chlorophyll content of autotrophic Scenedesmus cells.

\begin{tabular}{|c|c|c|c|c|c|c|}
\hline \multirow{2}{*}{ No. } & \multirow{2}{*}{ Compounds } & \multirow{2}{*}{$\mathrm{mp}\left({ }^{\circ} \mathrm{C}\right)$} & \multirow{2}{*}{$\begin{array}{c}\text { Growth }^{\mathrm{a})} \\
(\mu \mathrm{l} \mathrm{pcv/ml})\end{array}$} & \multicolumn{3}{|c|}{ Chlorophyll } \\
\hline & & & & $(\mu \mathrm{g} / \mathrm{ml})$ & Inhibition $\%$ b) & $(\mathrm{mg} / \mathrm{ml} \mathrm{pcv})$ \\
\hline & Control & & 3.8 & 29.75 & - & 7.83 \\
\hline 1 & & $125-126$ & 2.5 & 16.06 & 46.0 & 6.53 \\
\hline 2 & & $77-79$ & 3.5 & 24.50 & 17.7 & 7.02 \\
\hline 3 & & $137-140$ & 2.7 & 18.31 & 38.5 & 6.71 \\
\hline 4 & & $122-123$ & 3.1 & 21.81 & 26.7 & 6.99 \\
\hline 5 & & Oil & 4.1 & 31.13 & 0 & 7.69 \\
\hline 6 & & Oil & 3.9 & 26.44 & 11.1 & 6.80 \\
\hline 7 & & $92-94$ & 2.7 & 20.75 & 30.3 & 7.63 \\
\hline 8 & & $154-155$ & 4.0 & 30.38 & 0 & 7.67 \\
\hline 9 & & Oil & 3.5 & 24.63 & 17.2 & 7.04 \\
\hline 10 & & $151-153$ & 4.1 & 31.31 & 0 & 7.64 \\
\hline 11 & & $165-167$ & 2.0 & 7.59 & 61.0 & 3.80 \\
\hline
\end{tabular}


Table 1 (Continued.)

\begin{tabular}{|c|c|c|c|c|c|c|}
\hline \multirow{2}{*}{ No. } & \multirow{2}{*}{ Compounds } & \multirow{2}{*}{$\mathrm{mp}\left({ }^{\circ} \mathrm{C}\right)$} & \multirow{2}{*}{$\begin{array}{c}\text { Growtha) } \\
(\mu \mathrm{l} \text { pcv } / \mathrm{ml})\end{array}$} & \multicolumn{3}{|c|}{ Chlorophyll } \\
\hline & & & & $(\mu \mathrm{g} / \mathrm{ml})$ & Inhibition $\%^{\mathrm{b})}$ & $(\mathrm{mg} / \mathrm{ml} \mathrm{pcv})$ \\
\hline 12 & & $83-85$ & 1.5 & 3.06 & 89.7 & 1.99 \\
\hline 13 & & $84-85$ & 1.4 & 2.31 & 92.2 & 1.62 \\
\hline 14 & & $136-137$ & 2.4 & 6.82 & 73.6 & 2.84 \\
\hline 15 & & $166-167$ & 2.5 & 8.16 & 72.3 & 3.25 \\
\hline
\end{tabular}

a) Some swelling of cells occurs during incubation with peroxidizing herbicides. Real growth is less than indicated packed cell volume (pcv).

b) Percent ratio of reduced chlorophyll content against untreated control.

tion, Protox inhibition, and Proto-IX accumulation.

The three pyrazole compounds assayed accumulated Proto-IX at a $10^{-6} \mathrm{M}$ concentration in Scenedesmus cells as well as they caused ethane formation, chlorophyll decrease, growth inhibition, and inhibition of Protox. These findings are comparable to the activities obtained with the reference peroxidizing herbicides, namely oxyfluorfen (13) and S-23142 (14).

Thus the pyrazoles $(\mathbf{1}, \mathbf{1 1}$ and 12) were identified as peroxidizing herbicides, such as $p$-nitrodiphenyl ethers or cyclic imides. It is concluded that the bleaching activity of the pyrazole compounds discussed beforehand resulted mainly from peroxidative destruction of photosynthetic pigments, because this destruction was accompanied by ethane formation due to lipid peroxidation in cell membranes. It should be noted that the hydroxypyrazole derivative DTP (4-(2,4-dichlorobenzoyl)-1,3-dimethyl-5-hydroxypyrazole) does not produce ethane in the light. This bleaching property is due to carotenoid biosynthesis inhibition. ${ }^{17,18)}$

The order of peroxidizing activity of the three pyrazoles assayed was as follows; Compound $\mathbf{1 1} \simeq \mathbf{1 2}>\mathbf{1}$. The peroxidizing activity of the non-bicyclic pyrazole (11) and bicyclic pyrazole (12) were about the same as that of the reference peroxidizers, oxyfluorfen $(\mathbf{1 3})$ and S-23142 (14), but the non-bicyclic pyrazole (1) was a less active peroxidizer (see column of $\mathrm{pI}_{50}$ (Ethane) in Table 2). 5-Amino-4-cyanoor 5-chloro-3,4-tetramethylene-moiety on the pyrazole ring may contribute to produce a higher peroxidizing activity. The 1-(4-chlorofluoro-5-substituted)phenyl group appears to be essential for a stronger peroxidizing activity, as is true in cyclic imide, ${ }^{1,3,12)}$ triazolidine, ${ }^{1-8,12)}$ thiadiazolidine, ${ }^{1,2,6)}$ and oxazolodine ${ }^{1,13)}$ peroxidizing herbicides. It is noteworthy that the 1-(2, 6-dichloro-4-trifluoromethyl)phenyl substituent at the pyrazole (11) makes a contribution to produce a strong peroxidizer through a suitable combination with other substituents such as amino- and cyano groups. Based on such structure-activity considerations design and synthesis are under way in our laboratory 
Table 2 Comparison of phytotoxic activities of pyrazole derivatives.

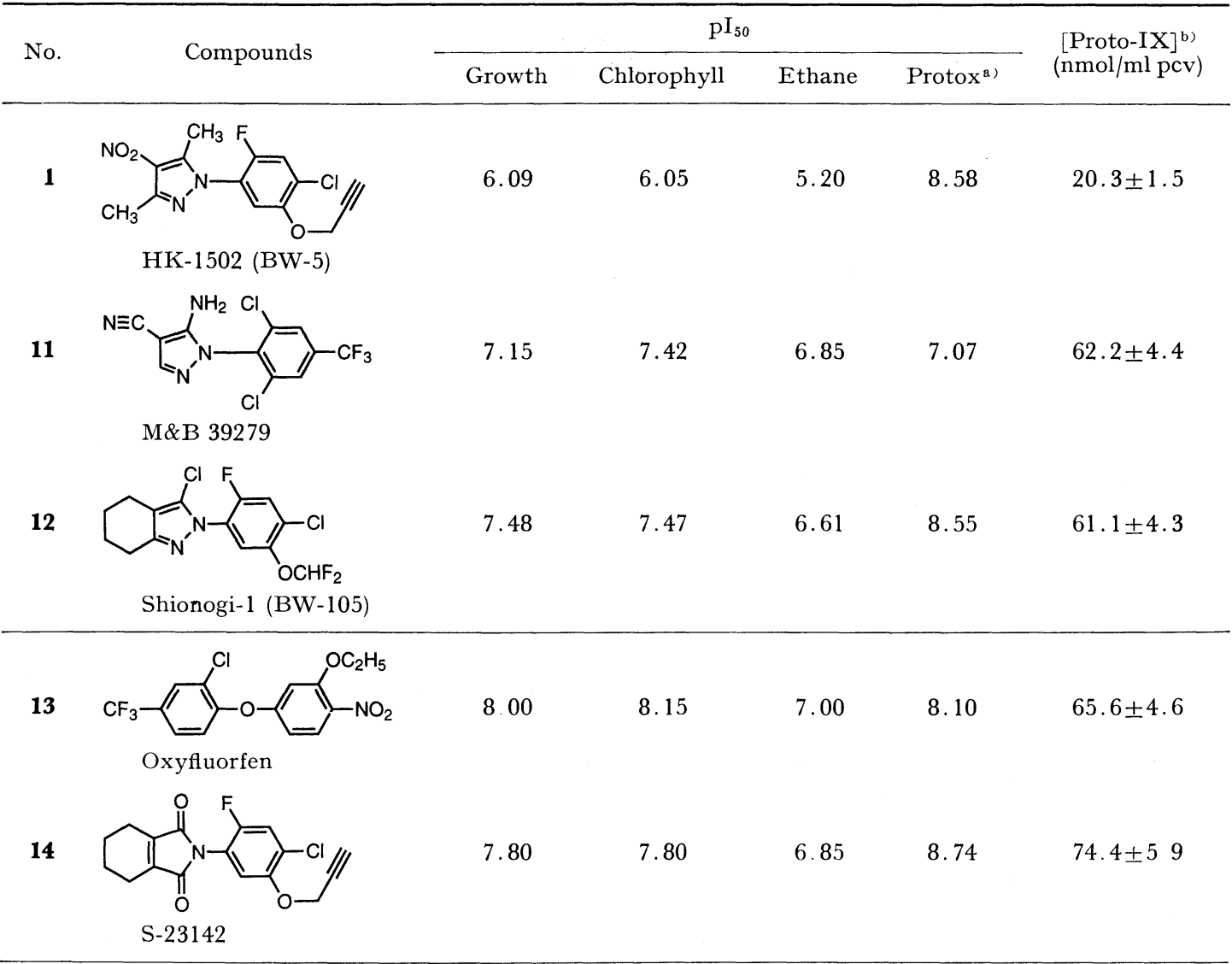

a) Protox inhibition was measured using isolated maize protoporphyrinogen-IX oxidase.

b) $\left[\right.$ Proto-IX] index is presented as proto-IX accumulation after a 1 -hr incubation with compounds at $10^{-6} \mathrm{M}$ concentration using autotrophic Scenedesmus cells according to Ref. 11).

to find out new active peroxidizers.

\section{ACKNOWLEDGMENTS}

The authors thank Dr. Hiroshi Ohyama, Hokko Chemical Industry Co., Ltd., and Dr. Toshikazu Ohtsuka, Shionogi \& Co., Ltd., for supplying pure samples of bleaching herbicides.

\section{REFERENCES}

1) K. Wakabayashi \& P. Böger: "Pesticide/Environment: Molecular Biological Approaches," ed. by T. Mitsui, F. Matsumura \& I. Yamaguchi, Pesticide Science Society of Japan, Tokyo, pp. 239-253, 1993

2) C. Ogino, T. Hoshi, T. Iida, S. Koura, H. Kohno, Y. Sato, M. Takai \& K. Wakabayashi: J. Pesticide Sci. 18, 369 (1993)

3) K. Wakabayashi, G. Sandmann, H. Ohta \& P.
Böger: J. Pesticide Sci. 13, 461 (1988)

4) H. Watanabe, Y. Ohori, G. Sandmann, K. Wakabayashi \& P. Böger: Pestic. Biochem. Physiol. 42, 99 (1992)

5) R. Lambert, G. Sandmann \& P. Böger: Pestic. Biochem. Physiol. 19, 309 (1983)

6) Y. Sato, T. Hoshi, T. Iida, C. Ogino, B. Nicolaus, K. Wakabayashi \& P. Böger: Z. Naturforsch. 49c, 49 (1994)

7) H. Ohyama, T. Ohno, T. Shimozono \& T. Terakawa (Hokko Chemical Ind. Co., Ltd.): Jpn. Kokai Tokkyo Koho JP 61-260065 (1986)

8) L. R. Hatton, E. W. Parnell \& D. A. Roberts (May \& Baker Ltd.): Jpn. Kokai Tokkyo Koho JP 58-23669 (1983)

9) Y. Hayase, T. Ohtsuka, K. Ide \& T. Takahashi (Shionogi \& Co., Ltd.): Jpn. Kokai Tokkyo Koho JP 62-30761 (1987) 
10) R. H. Yih \& C. Swithenbank: J. Agric. Food Chem. 23, 592 (1975)

11) B. Nicolaus, G. Sandmann, H. Watanabe, K. Wakabayashi \& P. Böger: Pestic. Biochem. Physiol. 35, 192 (1989)

12) B. Nicolaus, G. Sandmann \& P. Böger: "Target Assay for Moderen Herbicides and Related Phytotoxic Compounds," ed. by P. Böger \& G. Sandmann, Lewis Publ., Boca-Raton, U.S.A., pp. 34-41, 1993

13) H. Kohno, K. Hirai, M. Hori, Y. Sato, P. Böger \& K. Wakabayashi: Z. Naturforsch. 48c, 334 (1993)

14) G. Sandmann, I. E. Clarke, P. M. Bramley \& P. Böger: Z. Naturforsch. 39c, 443 (1984)

15) K. Wakabayashi: J. Pesticide Sci. 13, 337 (1988)

16) B. Nicolaus, G. Sandmann \& P. Böger: $Z$. Naturforsch. 48c, 326 (1993)

17) G. Sandmann, H. Reck \& P. Böger: J. Agric. Food Chem. 32, 868 (1984)

18) T. Soeda \& T. Uchida: Pestic. Biochem. Physiol. 29, 35 (1987)
要 約

新規ピラゾール化合物の植物に対するPeroxidizing 作用

河野 均，荻野千冬，飯田哲司，高須賀清司

佐藤幸治, Beate Nicolaus

Peter BöGER, 若林 攻

Scenedesmus 細胞とトゥモロコシの protoporphyrinogen-IX oxidaseを用いて，最近合成された 12 種 のピラゾール化合物の植物に対する peroxidizing 作用 について調べた. その結果, 1-(4-chloro-2-fluoro-5-propargyloxyphenyl)-3,5-dimethyl-4-trifluoromethylphenyl)pyrazole, 5-chloro - 1 - (4-chloro-5-difluoromethoxy-2-fluorophenyl)-3, 4-tetramethylenepyrazole の 3 種は, $10^{-6} \mathrm{M}$ 濃度で Scenedesmus 細胞の 生長を強く阻害し, クロロフィルの減少効果を引きおこ した．次にクロロフィル減少効果が，クロロフィル合成 阻害によるか，あるいはすでに生成しているクロロフィ ルの過酸化分解によるものかを決めるために, 定量的な 解析を行なった. その結果, 3 種のピラゾール化合物 は, protoporphyrinogen-IX oxidase を阻害し, protoporphyrin-IX を蓄積するばかりでなく，エタンを発 生し, クロロフィルを減少させ, 生長を阻害した. 以上 のことから，これらのピラゾール化合物は, peroxidizing 除草剤であることが確認された。ピラゾール環上の 1-(4-chloro-2-fluoro-5-置換) phenyl 置換基は，強い peroxidizing 除草剂を得るために重要なものと考えら れる。 